\title{
Clouds lift for turbulence-detector initiative
}

Rex Dalton, San Diego

Plans to develop a system for detecting air turbulence are gearing up again, three years after a lawsuit brought by an airline pilot halted the original research.

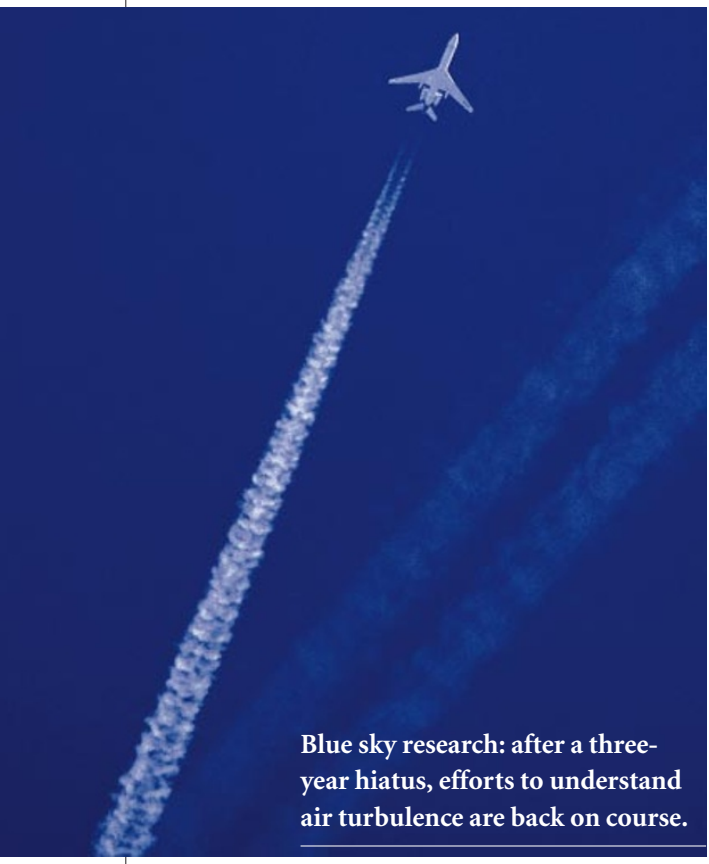

Unexpected turbulence causes hundreds of injuries every year on commercial flights and has resulted in the deaths of at least three people. But atmospheric physicists have had limited success in understanding the phenomenon, and it is difficult to predict precisely when and where turbulence will occur.

In 1995, Larry Cornman, a physicist at the National Center for Atmospheric Research (NCAR) in Boulder, Colorado, published details of software that can detect and quantify turbulence, and which gathers data on the conditions that create it. The software monitors the plane's vertical acceleration along with a dozen other factors such as altitude, speed and air temperature. A measure of the turbulence can then be transmitted to other aircraft approaching the same area (L. B. Cornman, C. S. Morse \& G. Cunning, J. Aircraft 32, 171-177; 1995).

A new version of Cornman's software is now being installed in aircraft. But the researchers involved say that a large portion of the US commercial fleet could already have been equipped with the system were it not for a lawsuit that halted the project in 1999.

The software had by then been installed in about 80 Boeing 737s as part of a collaboration between NCAR researchers, United
Airlines and aerospace company AlliedSignal (now merged with Honeywell, an engineering firm in Morristown, New Jersey). But the project stalled when Gary Bush, a pilot with Delta Airlines, filed a federal lawsuit in Fort Worth, Texas, alleging that the system infringed a patent he received in 1996 for a turbulencedetection system. Funding from the US Federal Aviation Administration (FAA) was withdrawn while the lawsuit was contested.

But NCAR researchers claim that the patent contains only vague details of a detection system and should not have been issued because of Cornman's earlier publication. Bush got no compensation when the case was settled last year, and the agreement left the NCAR free to use the data collected by its system for non-profit research.

Bush says that he never expected the FAA to stop funding the research, or the airlines to stop installing the software system, and that this is one of the reasons he settled the case.

The scientists who developed the software say that the case taught them an important lesson: don't rely on the published record of research to ensure free and unlimited access to a new technology. Securing a patent to ensure wide accessibility may be a better course of action, they say.

\section{Internecine rows threaten to sink whaling commission}

David Cyranoski, Tokyo

The annual meeting of the International Whaling Commission (IWC) is usually a fractious affair. But the recriminations surrounding this year's event, held in the former Japanese whaling port of Shimonoseki last week, have left some observers fearing for the organization's future in the face of increasingly bitter stand-offs between proand anti-whaling lobbies.

In 1986, the IWC voted for a moratorium on commercial whaling to protect diminishing stocks. The commission's scientific committee has since devised a computer model to allow sustainable quotas to be set, but the majority of anti-whaling nations has upheld the ban.

Japan is lobbying to overturn the moratorium, citing survey results that show that some whales, such as the minke, are abundant enough to support an end to the ban. But Japan's research programme, which includes the killing of some 600 whales per year, has garnered criticism - not least because the meat often ends up being sold for human consumption in Japan.

Japan's plan to take a further $\mathbf{5 0}$ minkes and 50 sei whales was attacked this year in a report submitted to the IWC's scientific committee by a research team led by Phil Clapham of the Northeast Fisheries Science
Center in Woods Hole, Massachusetts. The programme "provides no testable hypotheses and thus no reasonable criteria by which to judge its results", the report claims.

As expected, Japan's attempt to overturn the moratorium was rejected. But the big surprise was the voting down of a US-Russian request for a five-year extension to an agreement that allows aboriginal communities in Alaska and Chukotka, northeast Russia, to take a yearly quota of 280 endangered bowhead whales.

Japanese delegates, who voted against the extension, said that they opposed it because of US "hypocrisy" in rejecting a proposal for Japan's traditional whaling communities to be allowed to take 50 minkes. The vote "showed the anti-whaling countries that they couldn't do whatever they want", says Seiji Ohsumi, director of the Institute of Cetacean Research in Tokyo. But if such titfor-tat actions continue, there is a danger that the IWC will fall apart, raising the spectre of unregulated commercial whaling.

The IWC's scientific committee seems to be just as divided as its parent body. "It just puts together contradictory reports from the scientists representing the two sides," laments Toshio Kasuya, a whale-ecology researcher at Teikyo University of Science and Technology, west of Tokyo, who sits on the committee as an independent scientist.

Last week, Japan's fisheries agency said that its scientists will not take part in a meeting next month to analyse the techniques used in the country's research, citing scheduling difficulties. But some scientists claim that Japan is unwilling to have its research critically evaluated.

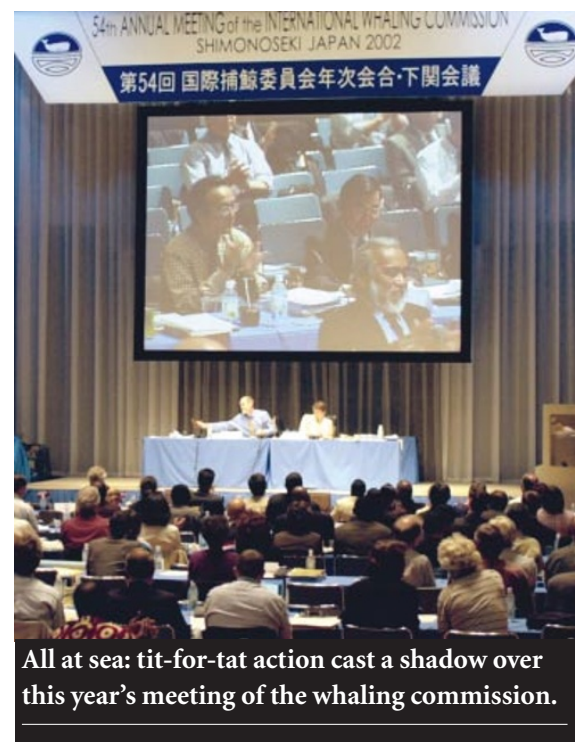

